\title{
Festa e Turismo Religioso: a procissão em louvor ao Nosso Senhor dos Passos na cidade de São Cristóvão (Sergipe - Brasil)
}

\author{
Feast and Religious Tourism: the Procession in Praise to "Nosso Senhor dos \\ Passos" in the city of São Cristóvão (Sergipe- Brazil)
}

\author{
Ivan Rêgo Aragão* \\ Janete Ruiz de Macedo ${ }^{* *}$
}

\begin{abstract}
Resumo
As festas realizadas pela Igreja Católica foram os primeiros eventos sociais no período do Brasil colônia, agregando pessoas de classes sociais distintas, mesclando as diferentes culturas e etnias. Estas foram motivo de congraçamento, mas também de pelejas e controle social realizado pela Igreja e Estado Português. Atualmente no Brasil, as festas católicas deslocam uma grande quantidade de pessoas no período dos seus acontecimentos. Além de atrativos turísticos, as celebrações religiosas no país são também patrimônio imaterial e estão inseridas dentro da cultura "do festejar" dos brasileiros. Esse presente artigo tem por finalidade abordar aspectos da Procissão ao Nosso Senhor dos Passos na cidade sergipana de São Cristóvão. A metodologia utilizada foi a pesquisa bibliográfica, com discussão no campo teórico sobre Barroco, Festa Devocional, Tradição, Religiosidade, Procissão, Turismo Religioso, Cultura e Identidade. Também foi realizada a pesquisa de campo, com observação direta. Com esse estudo, ficou perceptível que, como território distante de Portugal, as festas religiosas do Brasil tomaram uma dinâmica própria, absorvendo elementos profanos e se resignificando através do apelo popular.
\end{abstract}

Palavras-chave: Turismo Religioso; Catolicismo; Festa; Nosso Senhor dos Passos.

\begin{abstract}
The feasties held by the Catholic Church were the first social events during the period of colonial Brazil, bringing people from different social classes, merging the different cultures and ethnicities. These were the subject of harmony, but also of struggles and social control held by the Church and the Portuguese State. Currently in Brazil, the Catholic party moving a lot of people in the period of their events. Apart from tourist attractions, religious celebrations in the country are also intangible heritage and culture are embedded within "the feast" of Brazilians. This present article seeks to address aspects of the Procession of "Nosso Senhor dos Passos" the city of São Cristóvão state of Sergipe. The methodology used was literature, with discussion in the theoretical field of Baroque, Devotional Feast, Tradition, Religion, Procession, Religious Tourism, Culture and Identity. We also carried out field research, with direct observation.With this study, it was noticeable that, as distant territory of Portugal, the religious feasties in Brazil have taken a very dynamic, absorbing the profane elements and reframing through popular appeal.
\end{abstract}

Key words: Religious Tourism; Catholicism; Feast; Nosso Senhor dos Passos.

\footnotetext{
Artigo recebido em 31 de janeiro de 2011 e aprovado em 12 de maio de 2011.

* Mestrando em Cultura e Turismo pelo Programa de Pós Graduação Stricto Sensu da Universidade Estadual de Santa Cruz - UESC, Ilhéus/BA, com bolsa da CAPES. País de origem: Brasil. E-mail: ivan_culturaeturismo@hotmail.com

** Possui graduação em História pela Universidade Federal de Pernambuco (1975), graduação em Pedagogia pela Universidade Estadual de Santa Cruz (1981), especialização em História Moderna e Contemporânea pela Pontifícia Universidade Católica de Minas Gerais (1984) e doutorado em História da Antiguidade Clássica pela Universidad de Leon (2000). Atualmente é Professora Plena da Universidade Estadual de Santa Cruz e Membro de corpo editorial da Crítica \& Debate. País de origem: Brasil. E-mail: janetermacedo@yahoo.com.br
} 


\section{Introdução}

Concomitante a expansão ultramarina, se desenvolveu em grande parte do "Velho Continente" e, posteriormente em suas colônias, o modo de ser e ver o mundo por meio das idéias barrocas que foram exteriorizadas através da musica, da literatura, da arte sacra, ${ }^{1}$ e da religiosidade e, transplantadas para América Luso-Espanhola. À exemplo de outros países, o Brasil recebeu diversas influências desse legado cultural vindo da Europa. Através da exacerbação dos sentidos e da teatralização, o clero utilizou o movimento barroco como forma de auxiliar na adesão de novos fiéis.

Junto aos navegantes aventureiros, os padres jesuítas saíram para desbravarem o “mundo desconhecido". Sob a fé divina no céu e o poder do rei na terra, a América Portuguesa recebeu por todo o período em que foi colônia, os padres da Companhia de Jesus, da Irmandade Carmelita, Franciscana, Dominicana e Beneditina como um exército de soldados à serviço do sagrado, tendo o objetivo de trazer novas almas para dentro do catolicismo romano.

Porém, a catequização dos nativos do Brasil Colônia, não foi tarefa fácil, e nem poderia ser, visto que, os elementos do catolicismo europeu estavam fora do contexto cultural dos povos ameríndios. Os ensinamentos das expressões religiosas ligadas às práticas do catolicismo sofreram resistências, precisando que Portugal lançasse mão de estratégias para a assimilação dos rituais católicos. Uma dessas estratégias foi o estímulo às festas processionais de caráter devocional, através da teatralização, da dramaticidade e dá percepção dos cinco sentidos. Sendo costume em Portugal as festas em devoção aos santos, estas foram transferidas para a América Portuguesa. Alguns padres tendo como principio as teorias cristãs empreenderam por grande parte da colônia portuguesa, festejos em

\footnotetext{
${ }^{1}$ O Barroco foi o nome dado ao pensamento que floresceu na Europa, América e alguns pontos do oriente entre o início do século XVII e meados do século XVIII. No Brasil, foi introduzido no início do século XVII pelos missionários católicos da Companhia de Jesus, que trouxeram elementos da arte barroca européia como instrumento de doutrinação cristã. O Barroco é também chamado, de arte da Contra-Reforma, visto que, o clero investiu na dramatização, teatralidade e amplificação dos sentimentos como forma de persuadir os nativos da América Portuguesa à doutrina católica. Através do jogo claro-escuro, ilusão, cores vivas do vermelho, azul e do e da idéia de movimentos através das formas curvas e contracurvas, o barroco auxiliou os padres das Ordens Religiosas, transformarem as igrejas em espaços de êxtase dos sentidos. No enfoque de Affonso Ávila (1971), o Barroco é visto mais além do que um estilo artístico, mas como um conjunto de gostos estéticos que irradia para a vida em todos os seus significados: um estilo global de cultura e de época.
} 
invocações aos santos como forma de catequizar e instruir os nativos brasileiros.

Possibilitando que desde o século XVI até a atualidade, as festas em devoção aos santos desloquem pessoas procedentes de diversas partes do Brasil para as cidades pólos destes acontecimentos. Além de celebrar momentos especiais, as comemorações mantêm viva a tradição dos festejos nas cidades coloniais, possibilitando assim, que os acontecimentos festivos, tornem-se um verdadeiro patrimônio cultural.

Como São Cristóvão, fundada em 1590 por Cristóvão de Barros (NUNES, 2007). Cidade pertencente ao estado de Sergipe, e que, sempre no segundo final de semana após o Carnaval, ${ }^{2}$ realiza a celebração ao Nosso Senhor dos Passos. Com elementos do catolicismo barroco português transferido para o Brasil, a referida festa tem os caracteres processional e penitencial. Nos dois dias em que ela acontece, os últimos momentos do calvário de Jesus são rememorados através da imagem do Senhor do Passos, atraindo pessoas em romaria de vários lugares do estado e do Brasil, em devoção a Jesus Cristo sob essa invocação.

Esse presente artigo tem por finalidade abordar aspectos da procissão ao Senhor dos Passos na cidade sergipana de São Cristóvão. A metodologia utilizada foi a pesquisa bibliográfica, com discussão no campo teórico sobre Barroco, Festa Devocional, Tradição, Religiosidade, Procissão, Memória, Turismo, Cultura, Identidade, Religião e Turismo Cultural Religioso. Também foi realizada a pesquisa de campo, com observação direta. Com esse estudo, ficou perceptível que, como território distante de Portugal, as festas religiosas do Brasil tomaram uma dinâmica própria, absorvendo elementos profanos e se resignificando através do apelo popular.

\section{Festa Barroca}

No período que o Brasil tornou-se colônia de Portugal, a Europa passava por um momento de grandes mudanças. Principalmente no que tange a quebra das fronteiras geográficas com as grandes navegações, de paradigmas sobre o universo com as novas descobertas na astronomia e dos embates entre a religião cristã e protestante. Com o avanço das ideias de Lutero pelo continente europeu, a Igreja Católica sentiu-se ameaçada em seu poder criando a partir desse fato, o Concilio de Trento. É nesse momento que o barroco,

\footnotetext{
${ }^{2}$ A festa é celebrada 17 dias após o Carnaval dentro do período da Quaresma.
} 
tanto na arte, como em pensamento, [...] "adquire consistência ideológica - uma cosmovisão e uma práxis própria - e se define como estilo" [...] "no instante em que as fôrças de historicidade desencadeadas pela contra-reforma convergem para um eixo objetivo e se sedimentam num projeto de ação" (ÁVILA, 1971, p. 49).

Uma das ações do referido Conselho foi de arrebanhar novos adeptos para a religião cristã. O "Novo Mundo" até então desconhecido, surge como possibilidade de oferecer novas almas para perpetuar o poder da Igreja. Com o patrocínio das Coroas Portuguesa e Espanhola e o consentimento do Papa em Roma, os países da península ibérica se lançam nas "grandes navegações". Esse projeto empreendedor ainda tinha objetivos de criar novas rotas de comércio, somada a possibilidade de acumulação de metais preciosos própria do mercantilismo e também, de perenizar o poder monárquico.

Junto aos navegadores, a Igreja incentivou a vinda de missionários para adquirir “novas almas" para o catolicismo cristão (SOUZA, 1986). Mas a adesão de novos adeptos à religião católica no novo continente não foi uma empreitada fácil (SOUSA, 1993) e (VAINFAS, 1995). Frente ao grande número de adversidades culturais e ambientais enfrentadas pelos padres jesuítas e mais tarde os de outras Ordens, ${ }^{3}$ o Clero Português proclamou as festas como um dos meios de assimilação da doutrina cristã, e, como propagação do poder do Estado. Para Priore (1994, p. 31), "os jesuítas foram os pioneiros em detectar de que forma o espetáculo audiovisual podia tornar-se pastoral ou catequético". No Brasil colônia, as festas com procissões, missas e adoração aos santos, tornaram-se momentos únicos, pedagógicos e lúdicos ${ }^{4}$ na adesão dos novos adeptos à religião católica: o branco vindo do continente europeu, o negro africano e o ameríndio.

A festa também servia como mediação entre a metrópole e a colônia da América Portuguesa, estampando a mentalidade do poder real e religioso, bem como, propagando hábitos e costumes do homem ibérico. De acordo com Priore (1994, p. 11), "a presença do Estado metropolitano português nas cerimônias públicas não apenas marcava a sua assiduidade na Colônia, mas construía as relações entre os diversos grupos sociais e a

\footnotetext{
${ }^{3}$ De acordo com Orazem $(2008,27)$, a Ordem dos Carmelitas "chegou em 1580 em decorrência da União Ibérica vinda da Metrópole, ao mesmo tempo em que outras Ordens religiosas entravam na região como os Franciscanos e Beneditinos, pois antes disso Portugal só permitiu que o clero regular da região fosse formado pelos Jesuítas.

" Na obra intitulada "O lúdico e as projeções do mundo barroco" (1971), Affonso Ávila também destaca três características eminentes da arte barroca: o lúdico, a ênfase visual e o poder de persuasão.
} 
própria metrópole". Era natural que, a partir deste fato, ao mesmo tempo em que os acontecimentos festivos promoviam o congraçamento, serviam também para expor a força Régia e a hierarquização social.

Como expressão do Estado Moderno, no Brasil setecentista e oitocentista, as festas seguiam regras definidas em editais mesmo nos dias que a antecediam. Era o caso das festas nas cidades do ciclo do ouro, ${ }^{5}$ onde as obrigações dos moradores perpassavam não só por motivações saneadoras dos espaços urbanos, tais como limpeza das casas, colocação de luminárias ou fogueiras e os melhores panos nas janelas. Mas também, em relação à atitude emocional que os participantes deveriam ter nos dias do acontecimento, passível de multa e prisão (FIGUEIREDO, 1995).

Essas ações que precediam a festa também foram discutidas por Mary Del Priore em seu livro "Festas e Utopias no Brasil Colonial". A autora enfatiza que era tradição nos dias anteriores ao acontecimento festivo caiar, iluminar, decorar casas e ruas, bem como erguer mastros à porta das casas (PRIORE, 1994). Mesmo hoje faz parte da festa, colocar panos e toalhas nas janelas das casas, principalmente por onde a procissão com o santo irá passar.

Por todo o território, nas principais cidades coloniais como Rio de Janeiro, Belém, nas cidades coloniais de Minas Gerais, no nordeste do país (Recife e Olinda-Pe, Salvador e Santo Amaro e Cachoeira-Ba, São Cristóvão-Se), era possível ver dias de celebração com as procissões em homenagem aos santos, festas em comemoração a inauguração de uma igreja e as homenagens fúnebres a membros da família real. Transformando assim, o ato de festejar, em um momento de confraternização e de alívio momentâneo frente aos mandos da Coroa, mas também, de disputas políticas e hierarquização social.

Pela distancia entre a metrópole e a colônia, os acontecimentos festivos ao serem transferidos para a América Portuguesa tomaram uma função de destaque em reforçar os poderes da Monarquia e também, como forma de rememoração do exemplo de vida de Jesus e dos santos mártires, incutindo no imaginário dos colonizados, a força da Coroa Real e do Clero através do exemplo das virtudes divinas. As festas de caráter civil e religioso também foram incorporadas no cotidiano da colônia portuguesa.

\footnotetext{
${ }^{5}$ Dentre as cidades do Ciclo do Ouro Mineiro, encontram-se Tiradentes, Ouro Preto, São João Del Rey, Mariana, Diamantina, Sabará, Catas Altas, Serro do Frio, Congonhas do Campo, Piranga, Santa Rita Durão, Caeté, Santa Bárbara, entre outras.
} 
Ora sob as ordens da Coroa Portuguesa, ora fora dos olhos dela, o fato é que, em mais de 500 anos de história, alguns aspetos da cultura e religiosidade de Portugal e Espanha estão vivos no imaginário dos brasileiros através das festas, onde o sagrado e o profano quase sempre co-existem. Amaral (1998, p. 25) ao citar Émile Durkheim, corrobora com essa discussão da relação híbrida da festa. Para o autor,

[...] toda festa, mesmo quando puramente laica em suas origens, tem certas características de cerimônia religiosa, pois, em todos os casos ela tem por efeito aproximar os indivíduos, colocar em movimento as massas e suscitar assim um estado de efervescência, às vezes mesmo de delírio, que não é desprovido de parentesco com o estado religioso (DURKHEIM, 1968, p. 547).

Para Maluf (2001) e Amaral (2000), as festas religiosas de caráter devocional, fazem parte da vida dos brasileiros, sendo plausível falar em uma "cultura da festa" no país. São momentos ápices, que em sua maioria, servem para lembrar acontecimentos bíblicos ou da hagiografia ${ }^{6}$ dos santos através do calendário litúrgico, renovando os sentimentos em favor do catolicismo. Segundo Ferreira (2009, p. 11), "as festas religiosas são uma das mais antigas manifestações da vida social no Brasil. Elas diferem umas das outras conforme a época e a sociedade, mas, invariavelmente, representam os valores, reforçam as estruturas sociais e ajudam a construir a identidade de um grupo" [...].

$\mathrm{Na}$ atualidade, as festas brasileiras em devoção aos santos continuam atraindo multidões que chegam de diversas partes do Brasil, sendo as mesmas responsáveis ao longo do ano pelo fluxo de pessoas nas cinco regiões do país. Para Martins e Leite (2006), as celebrações de cunho sagrado dão instrumentação de identificar nesses eventos uma vivência do religioso incorporado ao cultural, possibilitando muitas vezes, a recuperação da própria identidade. Durkheim (2008), em seu livro "as formas elementares da vida religiosa" comenta que os indivíduos por se sentirem professando a mesma religião, e assim, compondo uma mesma coletividade, "sentem-se ligados uns aos outros pelo simples fato de terem uma fé comum (DURKHEIM, 2008, p. 28).

Em diversas cidades do Brasil são visíveis nas festas do calendário litúrgico, os aspectos da devoção Cristiana. Principalmente na Semana Santa, nos festejos do ciclo

\footnotetext{
${ }^{6}$ Consiste na descrição da vida do santo, beato, que são que são proclamados por algumas igrejas cristãs, sobretudo pela Igreja Católica, pela sua vida exemplar e pela prática de virtudes heróicas. É também a disciplina de estudo que se ocupa com a vida dos santos e sua veneração.
} 
junino e no Natal, onde as tradicionais festas católicas atraem pessoas para as igrejas, ruas, transformando esses ambientes, em espaços de sociabilidade e manifestação de caráter devocional sagrado e, em alguns casos, elementos que fogem a essa ótica, tornando-se profanos.

\section{Turismo Religioso}

Pesquisas $^{7}$ apontam que, o segmento do turismo religioso está em franco crescimento. No Brasil, esse tipo de segmento se fortalece, na medida em que como maior país católico do mundo, existe sobremaneira uma demanda para o desenvolvimento dessa prática. De acordo com Andrade (1995, p. 79), depois do turismo de férias e de negócios, o segmento que mais está se desenvolvendo é o turismo religioso, visto que, "[...] além dos aspectos místicos e dogmáticos - as religiões assumem o papel de agentes culturais pelas manifestações de valores antigos, de intervenção na sociedade atual e de preservação no que diz respeito ao futuro dos indivíduos e das sociedades".

É cada vez maior o número de pessoas que buscam na religião conforto para suas angústias, paz interior e como meio de preenchimento espiritual. Segundo dados da EMBRATUR (1999), no país, o turismo religioso cria um fluxo de aproximadamente 15 milhões de pessoas ao longo do ano nas diversas regiões do território nacional. É quase $10 \%$ da população se movendo pelo território nacional atraída por aspectos espirituais, pelo pedido de graças e por agradecer a intercessão do seu santo de devoção.

Nos estudos de Richards que debate o turismo cultural, esse é visto em uma ampla abrangência, incluindo o fluxo de pessoas envolvidas como o segmento religioso. Segundo o autor citado (2009, p. 26) apud $\mathrm{OMT}^{8}$ (2004), o turismo cultural é um:

[...] movimento de pessoas em busca de motivações essencialmente culturais, tais como excursões de estudo, teatralizações e excursões culturais, viagens para festivais e outros eventos culturais, visita a localidades e monumentos, viagens para estudar a natureza, folclore ou arte e peregrinações.

O Brasil (2008, p. 19), menciona que o turismo religioso "configura-se pelas

\footnotetext{
${ }^{7}$ Andrade (1995), Dias e Silveira (2003), EMBRATUR (1999), Maio (2006), MTur (2005), Oliveira (2004).

${ }^{8}$ Organização Mundial do Turismo.
} 
atividades turísticas decorrentes da busca espiritual e da prática religiosa em espaços e eventos relacionados às religiões institucionalizadas [...] tais como as de origem oriental, afro-brasileiras, espíritas, protestantes, católica, compostas de doutrinas, hierarquias, estruturas, templos, rituais, e sacerdócio". Nesse sentido, o turismo religioso como ramificação do turismo cultural, se propõe a estimular o deslocamento de pessoas aos locais de culto e peregrinação, onde as mesmas procuram o preenchimento e conforto espiritual. Para Dias (2003, p. 17):

\footnotetext{
O turismo religioso apresenta características que coincidem com o turismo cultural, devido à visita que ocorre num entorno considerado como patrimônio cultural, os eventos religiosos constituem-se em expressões culturais de determinados grupos sociais ou expressam uma realidade histórico-cultural expressiva e representativa de determinada região.
}

A Empresa Brasileira de Turismo em parceria com a Arquidiocese do Rio de Janeiro criou o catálogo denominado "Roteiros da Fé Católica". No Brasil, as principais cidades que são referências do catolicismo oficial pelo número de peregrinos são Juazeiro do Norte, no Ceará, terra do Padre Cícero; Nova Trento em Santa Catarina, onde se encontra o Santuário de Madre Paulina; Belém do Pará, na festa do Círio de Nazaré (registrada pelo IPHAN como patrimônio cultural imaterial), e, a mais conhecida, Aparecida do Norte, no estado de São Paulo, onde está o Santuário da Padroeira do Brasil Nossa Senhora Aparecida (EMBRATUR, 1999).

Importante ressaltar também, os lugares como Caicó no Rio Grande do Norte, com a festa e procissão dedicada a Nossa Senhora Sant'Ana (também registrada como patrimônio imaterial do Brasil), Bom Jesus da Lapa na Bahia, com o santuário e festa dedicado à Bom Jesus da Lapa, São Cristóvão em Sergipe, com a festa a Nosso Senhor dos Passos e Paudalho-Pe, que homenageia São Severino do Ramos. Ainda assim, por todo o território nacional, seja em grandes cidades ou médios e pequenos povoados, é possível perceber a devoção aos santos, beatos e padroeiros das cidades, com sua procissão anual, onde atrai a população urbana e rural para o ritual de adoração.

$\mathrm{Na}$ contemporaneidade, as religiões têm cumprido também, o papel de reforçar a identidade como forma de demarcar a cultura da sociedade. Burity (2002), afirma que o interesse pela identidade, diz respeito à percepção dos atores de que seu lugar no mundo 
passa por investimentos simbólicos, pelos quais eles se afirmam e negociam com outros sua forma de inserção na sociedade. Além disso, num mundo globalizado, o diferencial entre os grupos, instituições e indivíduos passa cada vez mais fortemente pela cultura, de forma que esta se torna uma perspectiva obrigatória de discussão do que são e para onde vão as sociedades contemporâneas.

Se "o homem é o resultado do meio cultural em que foi socializado", como nos informa Laraia (2001, p. 46), “[...] ele é um herdeiro de um longo processo acumulativo, que reflete o conhecimento e experiência adquiridas pelas numerosas gerações que o antecederam". É de supor que, as grandes transformações pelo qual o mundo tem passado com a agilidade dos processos históricos, refletem no meio e no indivíduo. Se a cultura do homem perpassa por fatores psicológicos que guiam o comportamento do indivíduo e seu grupo (GEERTZ, 1989), a religião é um dos fatores de identificação. Ela corrobora em fazer o homem como ser social se sentir aceito dentro do grupo ao qual pertence. Nesse contexto, as religiões somadas ao turismo tornaram um dos fenômenos sociais que mais tem se desenvolvido nos últimos anos.

Essas várias percepções acerca do sagrado e do deslocamento aos centros que são atraentes para a atividade turística possibilitam vislumbrar que, as características do turismo religioso se modificam de acordo com o lugar, à distância e a intenção da viagem. $\mathrm{O}$ fluxo de pessoas encaixadas neste segmento é sempre palco de polêmica, no sentido de entender os fatores motivacionais e psicológicos que agem em fazer as pessoas se deslocarem as cidades, procissões, lugares e templos sagrados. A discussão se instala na medida em que, muitas vezes, o viajante dessa modalidade, nem sempre usa os equipamentos e estrutura turística do lugar visitado ou não deixa dinheiro para a circulação econômica na cidade.

Para Carvalho et al $(2005$, p. 2), o turismo religioso se enquadra no momentos de lazer, pois romeiro, penitente e devoto ao sair para os eventos que reforçam a sua fé, executam esse tipo de turismo, “[...] não apenas no sentido de compromisso com o Santo de sua devoção, mas como forma de praticar o lazer de ruptura do seu cotidiano de trabalho", independente de fatores como meio de transporte, estadia, ou alimentação, averiguado na pesquisa de campo na Festa ao Nosso Senhor dos Passos. Esse fator é corroborado pelos estudos de Andrade (1995), que relativiza o uso dos equipamentos pelo turista religioso. 
Abreu e Coriolano (2003) discordam do pensamento de Carvalho et al, onde para elas, o deslocamento do seu entorno habitual é a única semelhança entre o romeiro e o turista simpático a religião que professa.

A viagem para o romeiro é a satisfação espiritual da busca do místico, sendo na maioria das vezes um ato de sacrifício. [...] Para o turista, é uma procura de satisfação religiosa mais do que prazer material [...]. O turista religioso conjuga na viagem o prazer com a fé, mas a motivação maior é o prazer de viajar, conhecer coisas e lugares novos (ABREU; CORIOLANO, 2003, p. 79).

Carlos Alberto Steil em sintonia com as autoras citadas também percebe que, os turistas que escolhem uma romaria como viagem de passeio, "[...] formam hoje uma nova categoria de romeiros, que se dirigem ao santuário por motivações que devem ser remetidas mais a uma estrutura de significados próprios ao universo laico das viagens do século XIX do que ao universo místico das peregrinações" (STEIL, 2003, p. 255). Nesse contexto conclui-se que todo romeiro é turista, visto que, a viagem implica em um deslocamento para um local fora do seu costume habitual e, obriga o viajante, em certa medida, utilizar algum tipo de transporte (salvo quando o deslocamento é feito a pé). Mas nem todo turista é romeiro, pois muitas vezes a visita a lugares e igrejas sagradas, pode estar atrelada a conhecimento cultural, observação, ou por curiosidade.

Os eventos religiosos, são momentos ápices onde o fiel pode expor a sua devoção tornando-a publica, renovando os votos em favor do Sagrado, bem como, da à possibilidade sair dos afazeres cotidiano, promovendo momentos de louvor, êxtase e fruição. Dessa forma, as festas religiosas de caráter devocional e de pagamento de promessa, são capazes de agregar pessoas solidárias a uma força maior e ao estimulo do deslocamento guiado pela fé espiritual.

\section{A festa de Nosso Senhor dos Passos}

A invocação ao Nosso Senhor dos Passos é uma das mais antigas no país. ${ }^{9}$ Desde o período do Brasil Colonial, através das irmandades mineiras, as festas ligadas a Quaresma e a Semana Santa são destaque no calendário litúrgico. Herdada de Portugal, a Irmandade do

\footnotetext{
${ }^{9}$ Essa temática é vista nos estudos das historiadoras Adalgisa Arantes Campos (2004) e Laura de Melo e Souza (2001).
} 
Senhor dos Passos se tornou na capitania de Minas Gerais, junto com a do Santíssimo Sacramento, um das principais associações de leigos a difundir o culto à Paixão de Cristo (CAMPOS, 2004). Segundo Souza (2001), as primeiras capelas erguidas nas Minas Setecentistas foram em favor de Nossa Senhora do Rosário, seguidas do Santíssimo Sacramento, São Miguel e Almas do Purgatório, Nossa Senhora das Mercês, da Conceição, São Francisco de Assis, Santana, Senhor dos Passos, Santo Antônio e São Gonçalo.

A Ordem religiosa Carmelita ajudou a difundir no Brasil o tema dos Passos, ao introduzir nas suas igrejas, a iconografia com essa temática específica. Pinturas de forro nos tetos, painéis e imagens de Cristo foram de forma recorrente, representados por essa invocação, somados ao culto e devoção a Santa Tereza D’Ávila iniciados com a contrareforma católica (BORGES, 2005). Dessa forma pode-se fazer a associação de que, a invocação ao Nosso Senhor dos Passos, era difundida pelo programa no culto das igrejas dessa Ordem, visto que, uma das temáticas no contexto carmelita, eram os Sete Passos da Paixão.

No século XIX em São Cristóvão, o festejo ao Senhor dos Passos estava diretamente ligado a elite açucareira da região (SANTOS e NUNES, 2005). A cidade de São Cristóvão foi criada em 1590 por Cristóvão de Barros, no período colonial do Brasil para servir de entreposto entre Salvador e Olinda (importantes postos comerciais) e proteger a região de contrabandistas franceses (NUNES, 2007). Seguindo o calendário litúrgico anual no segundo fim de semana da Quaresma, a cidade de São Cristóvão celebra e relembra a chegada de Jesus a Jerusalém, passando pela paixão, crucificação, morte e ressurreição. Desde o século XIX na cidade, esse momento é rememorado através da Procissão em louvor ao Senhor dos Passos (SANTOS e NUNES, 2005). São dois dias de celebração católica atraindo pessoas de vários lugares do Estado e do Brasil.

Ao estudar a festa em questão o historiador Bittencourt Júnior (2007) constatou os elementos simbólicos que imbricam a festa, tanto sob o ponto de vista do sagrado, como profano. Dessa forma, a festa é o período ápice para a externalização dos sentidos, das emoções devocionais, mas torna também visíveis fatores ligados à vida profana. Para o autor acima citado, a Procissão do senhor dos Passos em São Cristóvão, 
promesseiros, participam da comemoração políticos, vendedores ambulantes, pesquisadores, professores e estudantes, até os curiosos sem nenhum propósito, nesse contexto, a festa se caracteriza por diversas manifestações de caráter sacroprofano (BITTENCOURT JÚNIOR, 2007, p. 4).

Assim como Eliade (2008), concebeu essas duas categorias como sendo antagônicas, Durkheim (2008), corroborou com o autor anteriormente citado ao refletir que as coisas que envolvem a noção de sagrado, são opostas as da vivência do profano. Mas que embora, antagônicas, elas são interdependentes e co-existem para que a religião estabeleça os seus objetivos.

No final de semana que acontece a festa, a cidade de São Cristóvão, busca se estruturar para receber os milhares de fiéis vindos de várias partes do estado e do Brasil. Segundo dados do IBGE (2011), a população estimada em São Cristóvão é de 78. 876 habitantes. ${ }^{10}$ De acordo com a Prefeitura da cidade e a pastoral da comunicação Nossa Senhora da Vitória, a cidade duplica o numero de pessoas durante os dois dias de festa, perfazendo um total de 150.000 habitantes em média, entre os que são residentes e flutuantes. A edição da festa no ano de 2011 teve um público de 100 mil pessoas no sábado para a Missa Campal e Procissão da Penitência, e 50 mil pessoas no domingo para a Procissão do Encontro. ${ }^{11}$

O ritual católico festivo tem inicio a partir da sexta á noite, onde os fiéis rezam o quarto Ofício da Paixão de Jesus Cristo seguido de uma missa. Durante todo o dia de sábado fiéis, devotos, romeiros, promesseiro, penitentes e observadores, de diversas as partes começam a chegar à cidade de São Cristóvão. O grande fluxo é em direção a Igreja do Carmo Menor onde se encontram as imagens processionais do Senhor dos Passos e Nossa Senhora Das Dores. Algumas pessoas rezam em silêncio ou segurando na corda das imagens do "Senhor da Pedra Fria" ou o "Senhor da Coluna", centralizadas nos altares laterais da Igreja do Carmo Menor. Outros devotos adentram a igreja com os pés descalços e de joelhos como pagamento de promessa, há ainda os que trazem os seus ex-votos, ${ }^{12}$ como materialização da graça alcançada, deixando no museu anexo. Um grande número de devotos faz fila para passar em baixo do andor das imagens do Senhor dos Passos ou Nossa

\footnotetext{
${ }^{10}$ Disponível em: <http://www.ibge.gov.br/cidadesat/topwindow.htm?1〉. Acesso em: 25 de janeiro de 2011.

${ }^{11}$ Fonte: Prefeitura de São Cristóvão e Paróquia da Matriz de Nossa Senhora da Vitória.

12 Objetos referentes à graça alcançada pela interseção de Jesus, Maria ou outro santo. O termo ex-votos origina-se do latim ex-voto suscepto, isto é, "por força de uma promessa" ou "o voto realizado".
} 
Senhora das Dores, alguns fiéis acendem velas, amarram fitas nos braços, dentre outras ações. É um movimento intenso na igreja, antes de começar a missa campal no inicio da noite.

Logo após a missa campal, acontece a Procissão da Penitência também chamada de Procissão do Deposito, onde a pessoas do cortejo entoam cânticos ligados aos passos da Paixão. São paradas realizadas sempre em pontos estabelecidos e mantidos segundo a tradição da festa. Nestes locais, são erguidos pequenos altares representando o Passo a ser entoado pelos cantadores sempre em latim. Neste dia, a procissão sai da Igreja do Carmo Menor popularmente conhecida como Igreja Senhor dos Passos, seguindo pela Rua Pereira Lobo e dobrando à esquerda pela Praça Getúlio Vargas, até a Igreja Matriz Nossa Senhora da Vitória para o recolhimento da imagem. A imagem de Nosso Senhor dos Passos, é levada dentro de uma armação de madeira encoberta pelo encerro, ${ }^{13}$ onde fica até o domingo à tarde para a Procissão do Encontro.

As pessoas seguem em silêncio, outras cantando, algumas delas vestindo túnicas pretas, roxas e brancas, com velas nas mãos. Muitas pessoas vão descalças, ajoelhadas, algumas levam feixes de lenha na cabeça, os seus ex-votos, tais como retratos, fitas, bilhetes ou cabelos para colocar na Igreja. Em anos anteriores era comum ver pessoas, rolarem pelo chão de um passo para outro em pagamento de promessa. Ao final da procissão, antes da imagem adentrar a Igreja Matriz Nossa Senhora da Vitória, os devotos jogam suas túnicas na parte de cima do encerro como demonstração de fé e de agradecimento a Jesus sob esta invocação. Essas vestes são recolhidas pelas pessoas da paróquia para depois serem distribuídas aos pobres.

A Procissão do Encontro no domingo é o momento ápice da festa. É visível o registro de emoção e de fervor religioso, com pessoas batendo palmas, e chorando no encontro das imagens de Nosso Senhor dos Passos e Nossa Senhora das Dores. Essa procissão específica tem dois cortejos: um que segue a imagem de Jesus, saindo da Igreja Matriz Nossa Senhora da Vitória, seguindo pela Praça Getúlio Vargas, Rua Frei Santa Cecília, indo até a Praça São Francisco, nesse percurso, cantados três passos. Outro cortejo sai da Igreja do Carmo Maior acompanhando a imagem de Nossa Senhora das Dores em direção à mesma praça. A procissão passa pelas ruas Pereira Lobo, João Bebe Água e Leão

\footnotetext{
${ }^{13}$ Pano em tom de roxo que vela a imagem de Nosso Senhor dos Passos da visão externa dos fiéis.
} 
Magno, até chegar a Praça São Francisco. Ao se encontrarem a imagens são aplaudias e louvadas.

Pessoas querem tocar na cruz do Senhor dos Passos, e assim como acontece na procissão da noite anterior, os devotos tiram as túnicas e jogam para a imagem, sendo recolhidas por pessoas da paróquia. Após o sermão do Arcebispo de Aracaju, a Verônica sobe no pequeno púlpito e canta. Após esse momento, a Verônica se posta entre as duas imagens para seguir em um terceiro cortejo fazendo outro percurso, divergente dos anteriores, serpenteando pelas ruas do centro antigo da cidade. As imagens processionais seguem o trajeto pelas ruas Ivo do Prado, Praça Getúlio Vargas, Tobias Barreto, João Bebe Água, Leão Magno e Messias Prado. Sendo cantados sete passos retornando as duas imagens a Igreja do Carmo Menor, onde é realizado o recolhimento das Imagens e a missa campal de encerramento da festa.

\section{Considerações Finais}

Como herança barroca de matriz ibérica, das práticas de poder do Estado Moderno, bem como da Igreja, as festas com procissões no Brasil tornaram-se eventos tradicionais em mostrar a fé das pessoas. Sabe-se que além do fator de religiosidade, as comemorações tornaram-se também "lugar comum" para atitudes profanas, sobretudo em um país de grande extensão com diferentes costumes e mescla de etnias. Com a análise desse estudo, ficou perceptível que, como território distante de Portugal desde o período colonial, as festas de caráter religioso no Brasil, tomaram uma dinâmica própria.

Como extensão cultural dos brasileiros, as festas devocionais, acaba por reforçar a memória e a identidade, dando margem as pessoas se sentirem pertencendo ao mesmo grupo. As comemorações enquadradas na tradição cristã, além de relembrar a vida de santos, invocações de Jesus e Maria, reforçam a doutrina católica para a população brasileira. E nesse sentido, as festas ao longo do ano deslocam pessoas por todo o território nacional, fazendo com que, tornem-se encaixadas dentro do subsegmento do turismo cultural-religioso. Criando espaços, santuários e cidades consideradas próprias para a prática dessa atividade.

A Festa de Nosso Senhor dos Passos, é um acontecimento enquadrado dentro das 
comemorações da Semana Santa que tem um grande apelo penitencial. A partir do achado da imagem, há mais de 100 anos acontece à procissão reverenciando os últimos passos de Jesus. Atraindo pessoas de todo o Estado e do Brasil, transformando o acontecimento em um patrimônio imaterial da cidade de São Cristóvão.

\section{Referências}

ABREU, T. N. M. de; CORIOLANO, L. N. M. T. Os centros de romaria do Ceará e o turismo religioso. In: CORIOLANO, L. N. M. T. (Org.). O turismo de inclusão e o desenvolvimento local. Fortaleza: FUNECE, 2003. p. 78-95.

AMARAL, R. de C. Festa à brasileira: significados do festejar, no país que "não é sério". Tese de doutorado do Departamento de Antropologia, da Faculdade de Filosofia, Letras e Ciências Humanas da USP,1998.

AMARAL, R. de C. Sentidos da festa à brasileira. Disponível em: <http://www.naya.org.ar/congreso2000/ponencias/Rita_Amaral.htm>. Acesso em: 05 de outubro de 2010.

ANDRADE, J. V. de. Turismo: fundamentos e dimensões. 2. ed. São Paulo: Ática, 1995.

ÁVILA, A. O lúdico e as projeções do mundo barroco. São Paulo: Perspectiva, 1971.

BITTENCOURT JR, A. Penitentes do Senhor dos Passos, identidade e diversidade na religiosidade popular. In: Encontro Nacional de História das Religiões / ANPUH, Maringá, 2007.

BORGES, C. M. Santa Teresa e a espiritualidade mística: a circulação de um ideário religioso no Mundo Atlântico. In: $\mathbf{O}$ espaço atlântico de antigo regime: poderes e sociedades. Lisboa: Universidade Nova Lisboa, 2005, p. 1-10.

BRASIL, EMBRATUR. Roteiros da Fé. Rio de Janeiro: Arquidiocese, 1999.

BRASIL, Ministério do Turismo. Diretrizes para o desenvolvimento do turismo cultural. Brasília, DF, 2008.

BURITY, J. A. Cultura e identidade: perspectivas interdisciplinares. Rio de Janeiro: DP\&A, 2002.

CAMPOS, A. A. Piedade barroca, obras artísticas e armações efêmeras: as irmandades do Senhor dos Passos em Minas Gerais. In: Anais do VI Colóquio Luso-Brasileiro de História da Arte. Rio de Janeiro: CBHA / PUC-Rio / UERJ / UFRJ. Vol. 1. p. 1-13, 2004. 
CARVALHO, A. R. de M. et al. Religiosidades populares e a experiência do lazer: um estudo com romeiros de São Severino dos Ramos a partir da Teoria das Facetas. In: Anais do XVIII congresso de Ciências da comunicação - INTERCOM. Rio de Janeiro, 2005.

DIAS, R. O turismo religioso como segmento do mercado turístico. In: DIAS, R; SILVEIRA, E. J. S. da. (Orgs.). Turismo Religioso: ensaios e reflexões. Capinas: Alínea, 2003. p. 7-37.

DURKHEIM, É. As formas elementares da vida religiosa: o sistema totêmico na Austrália. 3. ed. São Paulo: Paulus, 2008.

ELIADE, M. O sagrado e o profano: a essência das religiões. Trad. Rogério Fernandes. 2. ed. São Paulo: Martins Fontes, 2008.

FERREIRA, L. D. M. e. Festas religiosas: uma manifestação cultural de Mariana. Ouro Preto ETFOP, 2009.

FIGUEIREDO, C. M. F. Festa e urbanidade em Mariana no século XVIII: a relação entre as festas e a organização da vida urbana. In: Revista do IFAC. Ouro Preto, UFOP, N $^{\mathbf{2}} 2$, 1995 , p. 62-67.

FIGUEIREDO, S. L. (Org.). Círio de Nazaré: festa e paixão. Belém: EDUFPA, 2005.

GEERZT, C. A interpretação das culturas. Rio de Janeiro: Livros Técnicos e Científicos, 1989.

LARAIA, R. de B. Cultura: um conceito antropológico. Rio de Janeiro: Jorge Zahar, 2001.

LIMA, M. É. de O. Uma reflexão comunicacional na festa popular do Padre Cícero. In:

Anais do Congresso da Associação Latino Americana de Investigadores da

Comunicação. Bolívia, 2002. p. 1-10.

MAIO, C. A. Turismo Religioso e desenvolvimento local. In: TREVIZAN, S. D. P. (Org.). Comunidades sustentáveis a partir do turismo com base local. Ilhéus: Editus, 2006.

MALUF, M. O aspecto barroco das festas populares. In: Revista Olhar, ano 3, $\mathrm{n}^{\mathrm{o}}$ 5-6, 2001, p. 1-6.

MARINHO, A. L. da S. O papel das redes geográficas do sagrado no turismo regional: o caso do Santuário de São Severino Mártir do Engenho Ramos Paudalho/PE. Anais do IV Encontro dos Estudos Multidisciplinares em Cultura (ENECULT). Salvado: UFBA, 2008.

MARTINS, C; LEITE, L. Cultura, religiosidade popular e romarias: expressões do patrimônio imaterial. In: MARTINS, C. (Org.). Patrimônio cultural: da memória ao sentido do lugar. São Paulo: Roca, 2006. 
MEDEIROS, J; CORIOLANO, L. N. M. T. A dimensão turística da festa de Sant'Ana em Caicó-RN. In: CORIOLANO, L. N. M. T; VASCONCELOS, F. P. O turismo e a relação sociedade-natureza: realidades, conflitos e resistências. Fortaleza: Ed. UECE, 2007.

NUNES, M. T. A Cidade de São Cristóvão na Formação da História Sergipana: da Colônia a nossos dias. In: Dossiê com a proposição de inscrição da Praça São Francisco em São Cristóvão/SE na lista do patrimônio mundial. Aracaju: Secretaria do Estado da InfraEstrutura, IPHAN, Prefeitura Municipal de São Cristóvão, 2007. CD ROM.

ORAZEM, R. B. A história da vida de Santa Tereza D’Ávila. Leitura iconográfica das pinturas de teto da sacristia da igreja da Ordem Terceira do Carmo. São Cristóvão, Sergipe. Monografia (Especialização em Artes Visuais). São Cristóvão: UFS, 2008.

PRIORE, M. D. Festa e utopia no Brasil Colonial. São Paulo: Brasiliense, 1994.

RICHARDS, G. Turismo cultural: padrões e implicações. In: CAMARGO P. de; CRUZ, G. da. Turismo cultural: estratégias, sustentabilidade e tendências. Ilhéus: Editus, 2009, p. $25-48$.

SANT'IAGO, S. Annuario Christovense ou Cidade de São Cristóvão. São Cristóvão, UFS, 2009.

SANTOS, M. F. de J; NUNES, V M. M. Na Trilha dos Passos do Senhor: a devoção ao Senhor dos Passos de São Cristóvão/SE. In: Revista da Fapese de Pesquisa e Extensão. Aracaju, v. 2, jul/dez. 2005, p. 97-110.

SANTOS, R. et al. Transformações sócio-culturais decorrentes do turismo religioso em Nova Trento - SC. In: TREVIZAN, S. D. P. (Org.). Comunidades sustentáveis a partir do turismo com base local. Ilhéus: Editus, 2006.

SOUSA, L. de M. e. O diabo e a terra de Santa Cruz: feitiçaria e religiosidade popular no Brasil colonial. São Paulo: Companhia das Letras, 1986.

SOUZA, L. de M. e. Inferno atlântico: demonologia e colonização. Séculos XVI-XVIII. São Paulo: Companhia das Letras, São Paulo, 1993.

SOUZA, L. de M. e. Festas barrocas e vida cotidiana em Minas Gerais. In: JANCSÓ, István; KANTOR, Iris. (Orgs.). Festa: cultura \& sociabilidade na América Portuguesa. v. 1. São Paulo: Edusp; Hucitec, 2001. p. 183-195.

STEIL, C. A. O sertão das romarias. Um estudo antropológico sobre o santuário de Bom Jesus da Lapa - Bahia. Petrópolis: Vozes, 1996.

STEIL, C. A. Romeiros e turistas no santuário de Bom Jesus da Lapa. In: Horizontes Antropológicos, Porto Alegre, v. 9, n. 20, 2003. p. 249-261. 
WERNET, A. Peregrinação a Aparecida: das romarias programadas ao turismo religioso. In: BALASTRERI, A. (Org.). Turismo, Modernidade, Globalização. 3. ed. São Paulo: Hucitec, 2002.

VAINFAS, R. (1995): A heresia dos índios - catolicismo e rebeldia no Brasil Colonial. São Paulo: Companhia das Letras, 1995. 